\title{
Spatial distribution of the daily precipitation concentration index in Algeria
}

\author{
A. Benhamrouche ${ }^{2}$, D. Boucherf ${ }^{1}$, R. Hamadache ${ }^{1}$, L. Bendahmane ${ }^{1}$, J. Martin-Vide ${ }^{2}$, and J. Teixeira Nery ${ }^{3}$ \\ ${ }^{1}$ National Climate Centre at the National Meteorological Office, Av. Khemisti B.P. 153, Dar el Beïda, Algiers, Algeria \\ ${ }^{2}$ Climatology Group, University of Barcelona, C/Montalegre 6, 08001 Barcelona, Spain \\ ${ }^{3}$ Department of Geography, UNESP Ourinhos, Av. Vitalina Marcusso, 1500 São Paulo, Brazil
}

Correspondence to: A. Benhamrouche (hydr21@yahoo.fr)

Received: 10 February 2014 - Published in Nat. Hazards Earth Syst. Sci. Discuss.: 23 April 2014

Revised: 7 December 2014 - Accepted: 17 February 2015 - Published: 18 March 2015

\begin{abstract}
In this paper, the spatial and temporal distribution of the daily precipitation concentration index (CI) in Algeria (south Mediterranean Sea) has been assessed. CI is an index related to the rainfall intensity and erosive capacity; therefore, this index is of great interest for studies on torrential rainfall and floods. Forty-two daily rainfall series based on high-quality and fairly regular rainfall records for the period from 1970 to 2008 were used. The daily precipitation CI results allowed the identification of three climate zones: the northern country, characterized by coastal regions with CI values between 0.59 and 0.63 ; the highlands, with values between 0.57 and 0.62, except for the region of Biskra $(\mathrm{CI}=0.70)$; and the southern region of the country, with high rainfall concentrations with values between 0.62 and 0.69 .
\end{abstract}

\section{Introduction}

The rainfall analysis with daily resolution in Algeria is a subject of great interest. This type of analysis is justified by the existence of severe environmental hazards in the Mediterranean, such as floods and soil instability resulting from the high percentages of annual total precipitation falling in a limited number of very rainy days. Thus, the area presents long periods of drought (Martin-Vide, 1994) and irregular temporal rainfall distribution in large areas of the western Mediterranean (Cortesi et al., 2012).

The interest is not only focused on climate but also on the effect of heavy rainfalls on other areas of the environment and society. However, the importance of daily precipi- tation has not been sufficiently studied. Only a few papers on the statistical structure of precipitation with daily resolution have been published. For example, studies of the Mediterranean basin (De Luis et al., 1996, 1997; Martin-Vide, 2004; Sánchez Lorenzo and Martin-Vide, 2006; Benhamrouche and Martin-Vide, 2011, 2012; Cortesi et al., 2012; Coscarelli and Caloiero, 2012) concluded that $25 \%$ of the rainiest days represent at least $75 \%$ of the annual total, and the highest values of the concentration index (CI) (over 0.66) are found on the eastern façade of peninsular Spain (from Barcelona to Almería). The results of similar studies in Iran (Alijani et al., 2008) and China (Zhang et al., 2009) indicated that the CI values detected in China were higher than in Iran (0.74-0.80 and $0.58-0.73$, respectively).

High CI values have been obtained in southeastern peninsular Spain and the geographical proximity to our study area invites us to focus on the spatiotemporal daily rainfall distribution of 42 meteorological stations evenly distributed over the entire Algerian territory. Statistical analysis was performed to determine the relative impact of different classes of daily precipitation and an assessment of accumulated rainfall.

The study of CI in Algeria is important due to its geographical position between the Mediterranean zone and the hot Sahara. The main objective of the article is to analyze the spatial distribution of the concentration of the daily precipitation in Algeria. The specific objectives are (1) to calculate the values of the CI, (2) map the CI values and (3) correlate the CI values with the values of other precipitation variables. 


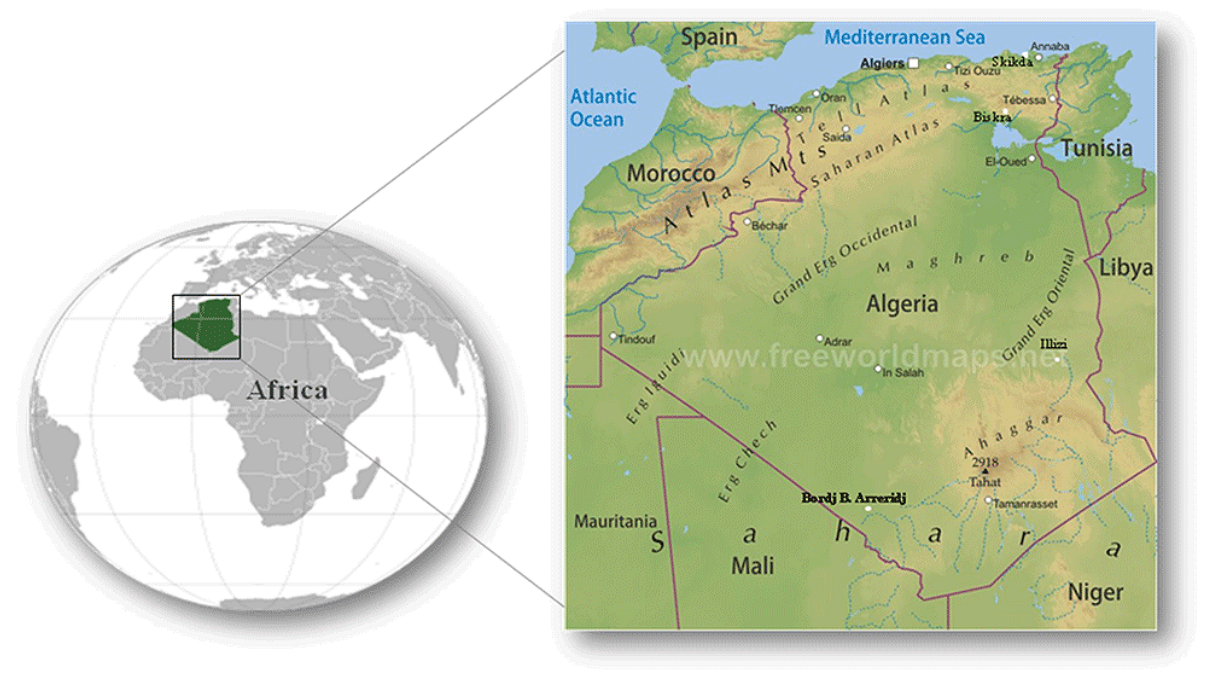

Figure 1. Geographical location of the study area (Algeria).

\section{Area of study}

Regardless of the variable or index analyzed, there is a need to study spatial precipitation patterns in Algeria to provide a better understanding of this phenomenon. These studies are relatively complex because of (1) the latitudinal position of Algeria between the Tropic of Cancer and the mid latitudes, which produces several climate zones, and (2) the considerable variety of altitudes, orientations and sloped reliefs.

Algeria, situated in northern Africa (between latitudes $19^{\circ}$ and somewhat over $37^{\circ} \mathrm{N}$ and longitudes $9^{\circ} \mathrm{W}$ and $12^{\circ} \mathrm{E}$ ), is the largest country on the continent, occupying an area of $2381740 \mathrm{~km}^{2}$ (Fig. 1). Algeria is bordered by the Mediterranean Sea to the north, Tunisia and Libya the east, Mauritania, Niger and Mali to the south, and Morocco and Western Sahara toward the west. The Saharan region (center and south of the country), accounting for $80 \%$ of the territory, is almost completely uninhabited.

Algeria's climatic regions and landscapes can be divided into three zones distributed parallel to each other along the country's N-S axis. Coastal Algeria has a Mediterranean climate with mild, rainy winters and hot, dry summers. Mean temperatures in January are above $10^{\circ} \mathrm{C}$ and slightly higher than $27^{\circ} \mathrm{C}$ in July. Average annual rainfall for Algeria is $83 \mathrm{~mm}$, but most of the northern area receives over $400 \mathrm{~mm}$ total annual precipitation, with some areas receiving more than $1270 \mathrm{~mm}$ according to the National Meteorological Office (ONM). The highest ranges of the Tell Atlas, which runs parallel to the coast, are $2290 \mathrm{~m}$ above sea level. The uneven terrain is interrupted by small plains, particularly along the coast. To the south of the Tell Atlas lie High Plateaus, characterized by a dry steppe climate with cooler winters and slightly hotter summers. Rainfall averages 250 to $500 \mathrm{~mm}$ annually, concentrated in winter and spring. The southernmost range of the Atlas mountains is the Saharan Atlas, which bor- ders on the desert. Though generally low, the Saharan Atlas reaches a height of over $2320 \mathrm{~m}$. It presents a very dry climate that is varied as a result of its elevation. Finally, much of the country is occupied by the Sahara desert, one of the world's most desolate areas, which has a tropical hot climate. Average summer temperatures are above $35^{\circ} \mathrm{C}$ and frequently rise as high as $43^{\circ} \mathrm{C}$ or over. Temperatures vary radically from day to night. Total precipitation is very low or almost zero; for example, in the extreme southeast of the country (Illizi, Bordj Badji Moukhtar, and Adrar), amounts lower than $20 \mathrm{~mm}$ are recorded. In the Hoggar mountains to the south lies Mount Tahat, Algeria's highest point, rising to $3000 \mathrm{~m}$.

\section{Data and method}

We obtained daily rainfall data for 42 Algerian weather stations from the ONM. The stations' recording periods varied in duration, but many data are available from 1970 to 2008 . We therefore selected stations that provide daily rainfall data presenting relatively uniform coverage throughout the country. The quality of the data series has been verified by the ONM. The station with less recorded data over the whole period has over $93 \%$ of the total data. Station characteristics are shown in Table 2 and their spatial distribution is mapped in Fig. 4.

The methodology applied in this study, proposed by Martin-Vide (2004) and including the definition of daily precipitation concentration and index, will be illustrated by an example (Table 1). Data from the Chlef station was available for the period from 1970 to 2008 . These meteorological stations do not show high daily precipitation values and, therefore, their frequency distribution can be presented in a moderate-length table. 


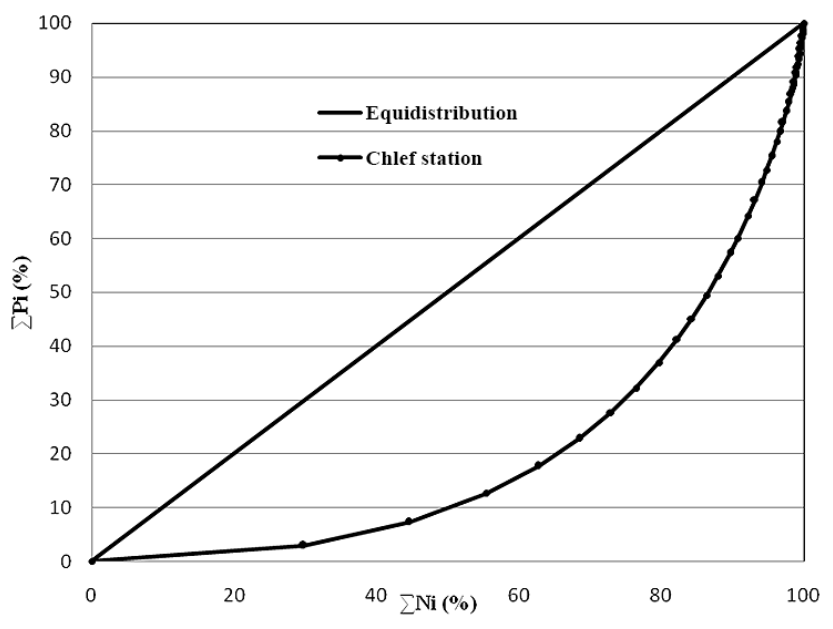

Figure 2. Concentration curve of Chlef meteorological station (1970-2008).

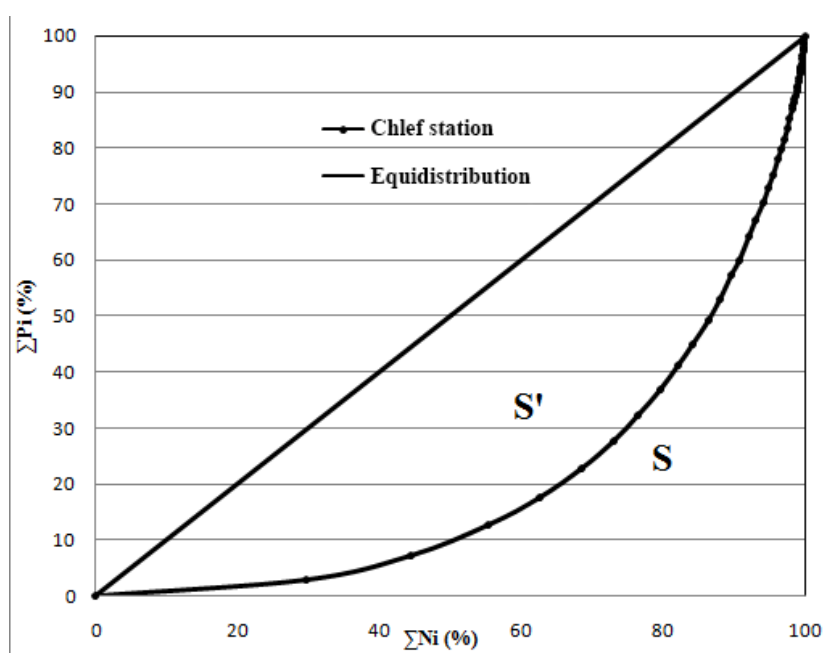

Figure 3. Concentration curve adjusted from the exponential curve of the Chlef meteorological station (1970-2008).

In the first column of Table 1, class limits are presented in ascending order and the second column shows their midpoints or centre of class. In the third column $(\mathrm{Ni})$ the number of recorded precipitation days in each class, or absolute frequency, is listed. For example, in 39 years, 819 rainy days were recorded with variant amounts from 0.1 to $0.9 \mathrm{~mm}$, and 407 rainy days represented amounts ranging from 1.0 to $1.9 \mathrm{~mm}$. The rainiest day is between 99.9 and $100.9 \mathrm{~mm}$. Overall, there were 2753 rainy days. The fourth column represents cumulative frequencies of rainy days $\left(\sum \mathrm{Ni}\right)$, which are obtained by adding the absolute frequencies of all classes (the last value of this column is the same as the total number of precipitation days). The fifth column is the total precipitation for each Pi class and is obtained by multiplying the corresponding Ni value (midpoint). The total accumulated rainfall $\left(\sum \mathrm{Pi}\right)$, in the sixth column, is obtained by progressively adding up the values of the previous column; the value of the last class is the total precipitation of $13958.5 \mathrm{~mm}$ recorded in the study period (1970-2008). The last two columns can be interpreted as follows: almost one-third of rainy days $(29.75 \%$ ), with $0.9 \mathrm{~mm}$ or less, represent only $2.93 \%$ of the total accumulated rainfall.

These results give the graphic representation shown in Fig. 2: the cumulative percentage of rainy days (next-tolast column of Table 1), $\sum \mathrm{Ni}(\%)$ or $X$ is plotted against the cumulative percentage of rainfall amounts (last column), $\sum \mathrm{Pi}(\%)$ or $Y$. Note that the resulting polygonal line is markedly exponential in the statistics and is called concentration curve or Lorenz.

However, we can refine Lorenz or concentration curves of the Chlef meteorological station by replacing polygons by exponential curves (Jolliffe and Hope, 1996). The work of Riehl (1949), Olascoaga (1950) and Martin-Vide (2004) showed that such functions are of the kind

$Y=a X \mathrm{e}^{b x}$,

with $a$ and $b$ as constants.

Parameters $a$ and $b$ of Eq. (1) were determined by the least squares method, given by Eqs. (2) and (3):

$\ln a=\frac{\sum x_{1}^{2} \sum \ln y_{1}+\sum x_{1} \sum x_{1} \ln x_{1}-\sum x_{1}^{2} \sum \ln x_{1}-\sum x_{1} \sum x_{1} \ln y_{1}}{N \sum x_{1}^{2}-\left(\sum x_{1}\right)^{2}}$

$b=\frac{N \sum x_{1} \sum \ln y_{1}+\sum x_{1} \sum \ln x_{1}-N \sum x_{1} \ln x_{1}-\sum x_{1} \sum \ln y_{1}}{N \sum x_{1}^{2}-\left(\sum x_{1}\right)^{2}}$,

where $N$ is the number of classes.

After determining the two constants $a$ and $b$, the definite integral of the exponential curve between 0 and 100 shows the area $S$ under the curve (the abscissa and the ordinate 100), which is given by the formula

$s=\left[\frac{a}{b} \mathrm{e}^{b x}\left(x-\frac{1}{b}\right)\right]_{0}^{100}$.

Based on $S$, the area $S^{\prime}$ compressed by the exponential curve, the equidistribution line and $X=100$ is the difference between 5000 and the value of $S$ (Fig. 3).

$S^{\prime}=5000-S$

Calculation of the CI given by the following formula from Martin-Vide (2004):

$\mathrm{CI}=S^{\prime} / 5000$.

Note that the CI value is a fraction of $S^{\prime}$ and the lower surface of the triangle is bounded by the equidistribution line.

In the case of the Chlef station, the application of Eqs. (2), (3) and (6) gives the following results: $a=0.036$, 
Table 1. Frequency distribution in classes of $1 \mathrm{~mm}$, relative cumulative frequencies $(X)$ and corresponding percentages of the total precipitation $(Y)$ in Chlef (1970-2008).

\begin{tabular}{|c|c|c|c|c|c|c|c|}
\hline Upper limit & Midpoint & $\mathrm{Ni}$ & $\Sigma \mathrm{Ni}$ & $\mathrm{Pi}$ & $\Sigma \mathrm{Pi}$ & $\Sigma \mathrm{Ni}(\%)=X$ & $\Sigma \mathrm{Pi}(\%)=Y$ \\
\hline 0.9 & 0.5 & 819 & 819 & 409.5 & 409.5 & 29.75 & 2.93 \\
\hline 1.9 & 1.5 & 407 & 1226 & 610.5 & 1020.0 & 44.53 & 7.31 \\
\hline 2.9 & 2.5 & 298 & 1524 & 745.0 & 1765.0 & 55.36 & 12.64 \\
\hline 3.9 & 3.5 & 202 & 1726 & 707.0 & 2472.0 & 62.70 & 17.71 \\
\hline 4.9 & 4.5 & 159 & 1885 & 715.5 & 3187.5 & 68.47 & 22.84 \\
\hline 5.9 & 5.5 & 123 & 2008 & 676.5 & 3864.0 & 72.94 & 27.68 \\
\hline 6.9 & 6.5 & 97 & 2105 & 630.5 & 4494.5 & 76.46 & 32.20 \\
\hline 7.9 & 7.5 & 88 & 2193 & 660.0 & 5154.5 & 79.66 & 36.93 \\
\hline 8.9 & 8.5 & 71 & 2264 & 603.5 & 5758.0 & 82.24 & 41.25 \\
\hline 9.9 & 9.5 & 56 & 2320 & 532.0 & 6290.0 & 84.27 & 45.06 \\
\hline 10.9 & 10.5 & 57 & 2377 & 598.5 & 6888.5 & 86.34 & 49.35 \\
\hline 11.9 & 11.5 & 45 & 2422 & 517.5 & 7406.0 & 87.98 & 53.06 \\
\hline 12.9 & 12.5 & 47 & 2469 & 587.5 & 7993.5 & 89.68 & 57.27 \\
\hline 13.9 & 13.5 & 28 & 2497 & 378.0 & 8371.5 & 90.70 & 59.97 \\
\hline 14.9 & 14.5 & 40 & 2537 & 580.0 & 8951.5 & 92.15 & 64.13 \\
\hline 15.9 & 15.5 & 27 & 2564 & 418.5 & 9370.0 & 93.13 & 67.13 \\
\hline 16.9 & 16.5 & 27 & 2591 & 445.5 & 9815.5 & 94.12 & 70.32 \\
\hline 17.9 & 17.5 & 19 & 2610 & 332.5 & 10148.0 & 94.81 & 72.70 \\
\hline 18.9 & 18.5 & 19 & 2629 & 351.5 & 10499.5 & 95.50 & 75.22 \\
\hline 19.9 & 19.5 & 20 & 2649 & 390.0 & 10889.5 & 96.22 & 78.01 \\
\hline 20.9 & 20.5 & 12 & 2661 & 246.0 & 11135.5 & 96.66 & 79.78 \\
\hline 21.9 & 21.5 & 11 & 2672 & 236.5 & 11372.0 & 97.06 & 81.47 \\
\hline 22.9 & 22.5 & 13 & 2685 & 292.5 & 11664.5 & 97.53 & 83.57 \\
\hline 23.9 & 23.5 & 10 & 2695 & 235.0 & 11899.5 & 97.89 & 85.25 \\
\hline 24.9 & 24.5 & 9 & 2704 & 220.5 & 12120.0 & 98.22 & 86.83 \\
\hline 25.9 & 25.5 & 3 & 2707 & 76.5 & 12196.5 & 98.33 & 87.38 \\
\hline 26.9 & 26.5 & 3 & 2710 & 79.5 & 12276.0 & 98.44 & 87.95 \\
\hline 27.9 & 27.5 & 3 & 2713 & 82.5 & 12358.5 & 98.55 & 88.54 \\
\hline 28.9 & 28.5 & 3 & 2716 & 85.5 & 12444.0 & 98.66 & 89.15 \\
\hline 29.9 & 29.5 & 5 & 2721 & 147.5 & 12591.5 & 98.84 & 90.21 \\
\hline 30.9 & 30.5 & 2 & 2723 & 61.0 & 12652.5 & 98.91 & 90.64 \\
\hline 31.9 & 31.5 & 1 & 2724 & 31.5 & 12684.0 & 98.95 & 90.87 \\
\hline 33.9 & 33.5 & 4 & 2728 & 134.0 & 12818.0 & 99.09 & 91.83 \\
\hline 34.9 & 34.5 & 2 & 2730 & 69.0 & 12887.0 & 99.16 & 92.32 \\
\hline 36.9 & 36.5 & 4 & 2734 & 146.0 & 13033.0 & 99.31 & 93.37 \\
\hline 37.9 & 37.5 & 1 & 2735 & 37.5 & 13070.5 & 99.35 & 93.64 \\
\hline 38.9 & 38.5 & 1 & 2736 & 38.5 & 13109.0 & 99.38 & 93.91 \\
\hline 39.9 & 39.5 & 1 & 2737 & 39.5 & 13148.5 & 99.42 & 94.20 \\
\hline 40.9 & 40.5 & 1 & 2738 & 40.5 & 13189.0 & 99.46 & 94.49 \\
\hline 41.9 & 41.5 & 2 & 2740 & 83.0 & 13272.0 & 99.53 & 95.08 \\
\hline 42.9 & 42.5 & 3 & 2743 & 127.5 & 13399.5 & 99.64 & 96.00 \\
\hline 43.9 & 43.5 & 1 & 2744 & 43.5 & 13443.0 & 99.67 & 96.31 \\
\hline 44.9 & 44.5 & 3 & 2747 & 133.5 & 13576.5 & 99.78 & 97.26 \\
\hline 45.9 & 45.5 & 1 & 2748 & 45.5 & 13622.0 & 99.82 & 97.59 \\
\hline 53.9 & 53.5 & 1 & 2749 & 53.5 & 13675.5 & 99.85 & 97.97 \\
\hline 57.9 & 57.5 & 1 & 2750 & 57.5 & 13733.0 & 99.89 & 98.38 \\
\hline 62.9 & 62.5 & 1 & 2751 & 62.5 & 13795.5 & 99.93 & 98.83 \\
\hline 63.9 & 63.5 & 1 & 2752 & 63.5 & 13859.0 & 99.96 & 99.29 \\
\hline 100.9 & 99.5 & 1 & 2753 & 99.5 & 13958.5 & 100.00 & 100.00 \\
\hline Sum & & 2753 & & 13958.5 & & 4448.27 & 3565.80 \\
\hline
\end{tabular}


Table 2. Geographic coordinates and average annual rainfall $(P)$, variation coefficient $(\mathrm{VC})$ and average number of rainy days $(N)$ for 42 meteorological stations across Algeria (during the period from 1970 to 2008).

\begin{tabular}{|c|c|c|c|c|c|c|c|}
\hline Station (code map) & Latitude & Longitude & Altitude (m) & Study period & $P(\mathrm{~mm})$ & $\mathrm{VC}(\%)$ & $N$ \\
\hline Adrar (AD) & $27^{\circ} 49^{\prime}$ & $-0^{\circ} 11^{\prime}$ & 279 & 1970-2008 & 18 & 99 & 11 \\
\hline Aïn Sefra (AS) & $32^{\circ} 46^{\prime}$ & $-0^{\circ} 36^{\prime}$ & 1058 & 1977-2008 & 166 & 57 & 50 \\
\hline Annaba (AN) & $36^{\circ} 50^{\prime}$ & $7^{\circ} 48^{\prime}$ & 3 & 1970-2008 & 651 & 23 & 120 \\
\hline Batna-Skhouna (BA) & $35^{\circ} 45^{\prime}$ & $6^{\circ} 19^{\prime}$ & 827 & 1972-2008 & 322 & 36 & 97 \\
\hline Béchar (BC) & $31^{\circ} 30^{\prime}$ & $-2^{\circ} 15^{\prime}$ & 807 & 1970-2008 & 91 & 56 & 36 \\
\hline Béjaia airport (BJ) & $36^{\circ} 43^{\prime}$ & $5^{\circ} 04^{\prime}$ & 2 & 1970-2008 & 770 & 46 & 109 \\
\hline Béni Abbès (BN) & $30^{\circ} 08^{\prime}$ & $-2^{\circ} 10^{\prime}$ & 499 & 1970-2008 & 36 & 76 & 22 \\
\hline Biskra (BK) & $34^{\circ} 48^{\prime}$ & $5^{\circ} 44^{\prime}$ & 82 & 1970-2008 & 125 & 46 & 42 \\
\hline Bordj Bou Arréridj (BB) & $36^{\circ} 04^{\prime}$ & $4^{\circ} 46^{\prime}$ & 928 & 1981-2008 & 337 & 37 & 87 \\
\hline Chlef $(\mathrm{CH})$ & $36^{\circ} 12^{\prime}$ & $1^{\circ} 20^{\prime}$ & 143 & 1970-2008 & 361 & 27 & 77 \\
\hline Constantine (CO) & $36^{\circ} 17^{\prime}$ & $6^{\circ} 37^{\prime}$ & 694 & 1970-2008 & 523 & 28 & 114 \\
\hline Dar El Beïda (DB) & $36^{\circ} 41^{\prime}$ & $3^{\circ} 13^{\prime}$ & 25 & 1970-2008 & 643 & 30 & 112 \\
\hline Djelfa (DJ) & $34^{\circ} 20^{\prime}$ & $3^{\circ} 23^{\prime}$ & 1180 & 1971-2008 & 311 & 33 & 90 \\
\hline El Bayadh (EB) & $33^{\circ} 40^{\prime}$ & $-1^{\circ} 00^{\prime}$ & 1341 & 1971-2008 & 256 & 39 & 85 \\
\hline El Goléa (EG) & $30^{\circ} 34^{\prime}$ & $2^{\circ} 52^{\prime}$ & 397 & 1970-2008 & 36 & 75 & 17 \\
\hline El Kheiter (EK) & $34^{\circ} 09^{\prime}$ & $0^{\circ} 04^{\prime}$ & 1000 & 1978-2008 & 204 & 39 & 68 \\
\hline Guemar, El Oued (OG) & $33^{\circ} 30^{\prime}$ & $6^{\circ} 47^{\prime}$ & 64 & 1970-2008 & 73 & 53 & 34 \\
\hline Ghardaïa (GH) & $32^{\circ} 24^{\prime}$ & $3^{\circ} 48^{\prime}$ & 468 & 1970-2008 & 74 & 51 & 31 \\
\hline Hassi Messaoud (HM) & $31^{\circ} 40^{\prime}$ & $6^{\circ} 09^{\prime}$ & 142 & 1970-2008 & 38 & 66 & 19 \\
\hline In Amenas (IA) & $28^{\circ} 03^{\prime}$ & $9^{\circ} 38^{\prime}$ & 561 & 1970-2008 & 26 & 97 & 15 \\
\hline In Salah (IS) & $27^{\circ} 14^{\prime}$ & $2^{\circ} 30^{\prime}$ & 268 & 1970-2008 & 16 & 97 & 16 \\
\hline M'sila (MI) & $35^{\circ} 40^{\prime}$ & $4^{\circ} 30^{\prime}$ & 441 & $1977-2008$ & 181 & 39 & 43 \\
\hline Maghnia (MG) & $34^{\circ} 49^{\prime}$ & $-1^{\circ} 47^{\prime}$ & 427 & 1976-2008 & 288 & 27 & 64 \\
\hline Matmore, Mascara (MS) & $35^{\circ} 36^{\prime}$ & $0^{\circ} 18^{\prime}$ & 474 & 1977-2008 & 320 & 31 & 72 \\
\hline Miliana (ML) & $36^{\circ} 18^{\prime}$ & $2^{\circ} 14^{\prime}$ & 715 & 1971-2008 & 746 & 28 & 109 \\
\hline Mostaganem Ville (MO) & $35^{\circ} 53^{\prime}$ & $0^{\circ} 07^{\prime}$ & 137 & 1976-2008 & 357 & 30 & 65 \\
\hline Es Sénia, Oran (OR) & $35^{\circ} 38^{\prime}$ & $-0^{\circ} 36^{\prime}$ & 90 & 1970-2008 & 352 & 27 & 82 \\
\hline Saïda (SD) & $34^{\circ} 52^{\prime}$ & $0^{\circ} 09^{\prime}$ & 750 & 1977-2008 & 323 & 32 & 76 \\
\hline Aïn Sfiha, Sétif (ST) & $36^{\circ} 11^{\prime}$ & $5^{\circ} 15^{\prime}$ & 1033 & 1981-2008 & 404 & 23 & 97 \\
\hline Skikda port (SK) & $36^{\circ} 53^{\prime}$ & $6^{\circ} 54^{\prime}$ & 1 & 1970-2008 & 725 & 22 & 108 \\
\hline Tamanrasset airport (TA) & $22^{\circ} 48^{\prime}$ & $5^{\circ} 26^{\prime}$ & 1362 & 1970-2008 & 49 & 76 & 26 \\
\hline Tébessa (TB) & $35^{\circ} 25^{\prime}$ & $8^{\circ} 07^{\prime}$ & 820 & $1972-2008$ & 346 & 38 & 90 \\
\hline Tiaret (TI) & $35^{\circ} 21^{\prime}$ & $1^{\circ} 28^{\prime}$ & 977 & $1983-2008$ & 335 & 27 & 89 \\
\hline Timimoun (TM) & $29^{\circ} 15^{\prime}$ & $0^{\circ} 17^{\prime}$ & 312 & 1970-2008 & 21 & 93 & 11 \\
\hline Tindouf (TN) & $27^{\circ} 42^{\prime}$ & $-8^{\circ} 10^{\prime}$ & 443 & 1970-2008 & 34 & 84 & 15 \\
\hline Tlemcen Zenata (TL) & $35^{\circ} 01^{\prime}$ & $-1^{\circ} 28^{\prime}$ & 210 & 1980-2008 & 310 & 27 & 65 \\
\hline Touggourt (TG) & $33^{\circ} 04^{\prime}$ & $6^{\circ} 05^{\prime}$ & 85 & 1974-2008 & 65 & 59 & 19 \\
\hline Bordj Badji Mokhtar (BM) & $21^{\circ} 20^{\prime}$ & $0^{\circ} 57^{\prime}$ & 397 & 1993-2008 & 20 & 58 & 5 \\
\hline Illizi (IL) & $26^{\circ} 30^{\prime}$ & $8^{\circ} 26^{\prime}$ & 543 & 1992-2008 & 11 & 74 & 4 \\
\hline Ouargla (Ou) & $31^{\circ} 56^{\prime}$ & $5^{\circ} 24^{\prime}$ & 144 & 1990-2008 & 21 & 78 & 10 \\
\hline In Guezzam (IG) & $19^{\circ} 34^{\prime}$ & $5^{\circ} 46^{\prime}$ & 400 & 1994-2008 & 25 & 95 & 5 \\
\hline Asskrem (AK) & $23^{\circ} 16^{\prime}$ & $5^{\circ} 38^{\prime}$ & 2710 & 1980-2008 & 132 & 60 & 35 \\
\hline
\end{tabular}

$b=0.033$ and $\mathrm{CI}=0.59 . \mathrm{CI}>0.61$ is high, $0.55<\mathrm{CI}<0.61$ is moderate and $\mathrm{CI}<0.55$ is low. The calculations were performed using software developed using Delphi (see Supplement 1 and 2).

Spatial interpolation methods, particularly the kriging technique, yield better results than other techniques, since kriging produces the standard error for the estimated values. Among all the kriging methods, ordinary kriging is used in this study. Statistical software was used for kriging applica- tion while mapping of the results was done using ArcGIS 10.1. The correlation methods used for each pair of variables - $(\mathrm{CI}, P),(\mathrm{CI}, \mathrm{CV})$ and $(\mathrm{CI}, N)$ - are the Pearson's correlation coefficient, Spearman's rho and Kendall's tau- $b$.

\section{Results and discussion}

The exponential curves of a given type in Eq. (1) were calculated for 42 meteorological stations in Algeria for the period from 1970 to 2008 (Table 3 and Fig. 5). Extreme values 


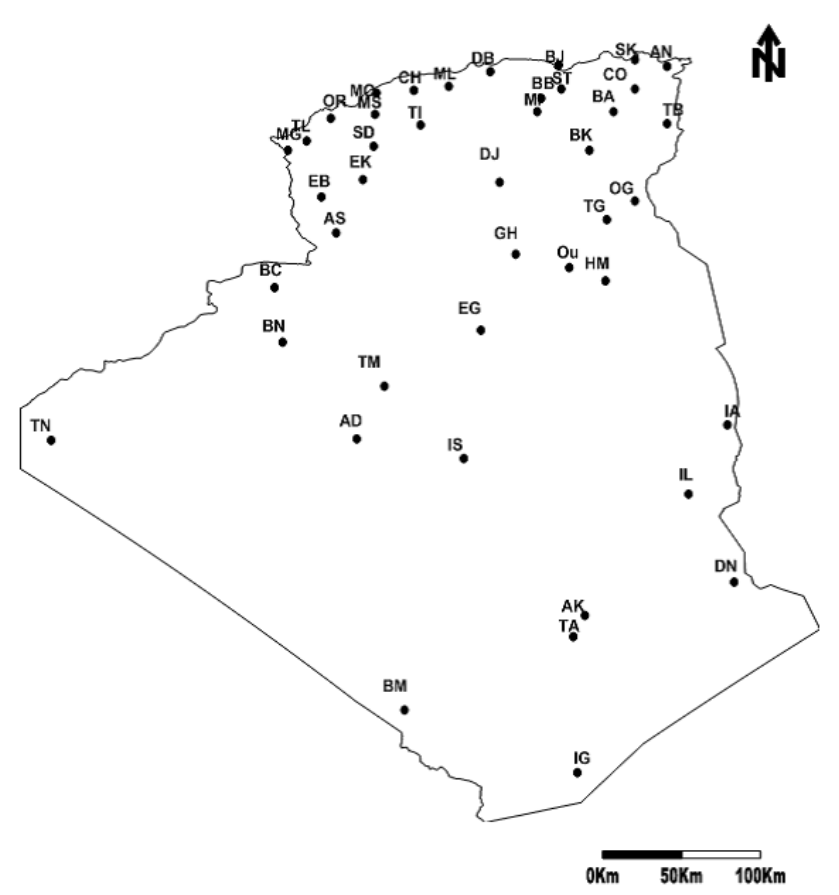

Figure 4. Location of meteorological stations analyzed (19702008).

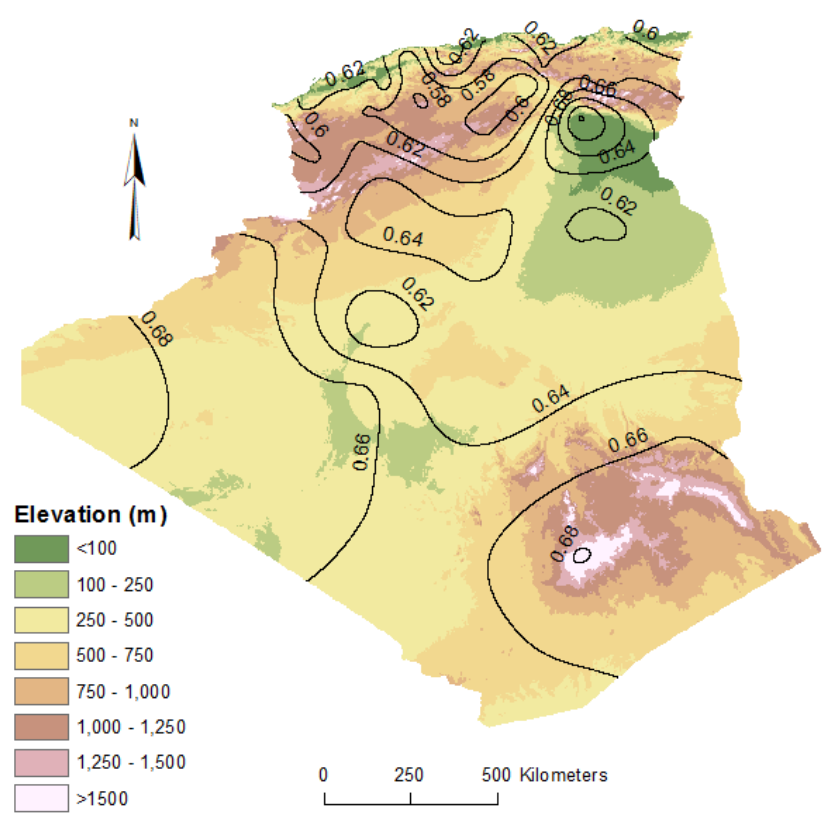

Figure 5. Spatial distribution of CI values in Algeria.

are $\mathrm{CI}=0.57$ in M'sila (mid-northeast Algerian territory), an area influenced simultaneously by the Saharan climate and the Mediterranean climate, and $\mathrm{CI}=0.70$ in Biskra (mideastern Algeria) with characteristics of marked rainfall by the Saharan climate. Despite the minimal distance between the two stations, a significant difference is observed with a
Table 3. Values of constants $a$ and $b$ of the exponential curves given by Eq. (1). The concentration index (CI) and the rainfall percentage contributed by $25 \%$ of the rainiest days for 42 weather stations across Algeria (during the period of 1970-2008).

\begin{tabular}{lrrrr}
\hline Station (code map) & $a$ & $b$ & CI & Rainfall $(\%)$ \\
\hline Adrar (AD) & 0.023 & 0.036 & 0.66 & 76.2 \\
Ain Sefra (AS) & 0.021 & 0.037 & 0.65 & 75.9 \\
Annaba (AN) & 0.034 & 0.033 & 0.59 & 70.2 \\
Batna-Skhouna (BA) & 0.031 & 0.034 & 0.61 & 73.0 \\
Béchar (BC) & 0.019 & 0.038 & 0.66 & 76.0 \\
Béjaia airport (BJ) & 0.024 & 0.036 & 0.63 & 73.0 \\
Béni Abbès (BN) & 0.022 & 0.036 & 0.66 & 76.1 \\
Biskra (BK) & 0.017 & 0.040 & 0.70 & 77.1 \\
Bordj B. Arreridj (BB) & 0.030 & 0.034 & 0.62 & 73.0 \\
Chlef (CH) & 0.036 & 0.033 & 0.59 & 70.2 \\
Constantine (CO) & 0.028 & 0.035 & 0.62 & 72.5 \\
Dar El Beida (DB) & 0.025 & 0.036 & 0.62 & 72.9 \\
Djelfa (DJ) & 0.043 & 0.031 & 0.58 & 70.5 \\
El Bayadh (EB) & 0.036 & 0.032 & 0.60 & 72.0 \\
El Golea (EG) & 0.027 & 0.035 & 0.64 & 74.8 \\
El Kheiter (EK) & 0.029 & 0.034 & 0.62 & 72.5 \\
El Oued Guemar (OG) & 0.025 & 0.036 & 0.64 & 74.9 \\
Ghardaïa (GH) & 0.025 & 0.036 & 0.64 & 75.3 \\
Hassi Messaoud (HM) & 0.039 & 0.031 & 0.62 & 73.5 \\
In Amenas (IA) & 0.026 & 0.035 & 0.64 & 75.0 \\
In Salah (IS) & 0.023 & 0.037 & 0.63 & 74.9 \\
M'sila (MI) & 0.058 & 0.028 & 0.57 & 66.0 \\
Maghnia (MG) & 0.036 & 0.032 & 0.60 & 70.9 \\
Mascara Matmore (MS) & 0.036 & 0.032 & 0.60 & 71.0 \\
Miliana (ML) & 0.020 & 0.038 & 0.65 & 70.0 \\
Mostaganem Ville (MO) & 0.024 & 0.036 & 0.64 & 74.0 \\
Es Sénia, Oran (OR) & 0.026 & 0.036 & 0.63 & 74.0 \\
Saida (SD) & 0.035 & 0.033 & 0.60 & 71.0 \\
Aïn Sfiha, Sétif (ST) & 0.029 & 0.035 & 0.61 & 72.0 \\
Skikda Port(SK) & 0.033 & 0.033 & 0.60 & 71.0 \\
Tamanrasset airport (TA) & 0.020 & 0.037 & 0.67 & 77.0 \\
Tébessa (TB) & 0.028 & 0.035 & 0.62 & 72.5 \\
Tiaret (TI) & 0.045 & 0.030 & 0.58 & 69.0 \\
Timimoun (TM) & 0.057 & 0.026 & 0.61 & 71.8 \\
Tindouf (TN) & 0.021 & 0.036 & 0.69 & 79.0 \\
Tlemcen Zenata (TL) & 0.027 & 0.035 & 0.62 & 73.0 \\
Touggourt (TG) & 0.029 & 0.034 & 0.63 & 72.5 \\
Bordj Badji Mokhtar (BM) & 0.024 & 0.036 & 0.65 & 76.0 \\
Illizi (IL) & 0.029 & 0.033 & 0.66 & 77.5 \\
Ouargla (Ou) & 0.028 & 0.035 & 0.62 & 74.0 \\
In Guezzam (IG) & 0.053 & 0.026 & 0.65 & 73.5 \\
Assekrem (AK) & & & & 78.8 \\
\hline & & 0.039 & 0.68 & \\
& & & \\
\hline
\end{tabular}

variation coefficient of $13 \%$ from the surface exponentially compressed by the two stations and the equidistribution line. This means that the daily rainfall patterns are quite different.

Through the exponential concentration curves, the rainfall percentage contributed $25 \%$ of the rainiest days, i.e., those with larger amounts were calculated. The results are presented in Table 3. Extreme rainfall values can be found in Tindouf, with $79 \%$, and M'sila, with $66 \%$ (Table 3).

Note that in the first case, as in other stations (Illizi Assekrem and Bordj Badji Mokhtar) in southern Algeria, the 
fourth part of rainy days represent $75 \%$ of total rainfall. This leads to a marked uncertainty in terms of annual rainfall considering the low number of rainy days per year obtained.

Any anomaly in atmospheric general circulation can greatly increase or reduce the total annual precipitation.

\subsection{Regionalization of the concentration index in Algeria}

\subsubsection{Analysis of the geographical and spatial patterns of the daily concentration precipitation in Algeria}

The geographic and spatial patterns of daily rainfall concentrations in Algeria have been analyzed. The CI values of Table 3 are shown in Fig. 5 through isopleths, which allow the determination of the spatial distribution of the daily precipitation concentration in a large part of Algeria. By analyzing the values obtained, three climatic zones can be determined. The first area in northern Algeria is characterized by coastal regions with the CI values ranging from 0.63 , nearly identical to western Algeria (except for the Mostaganem region $=0.64$ ) and center of the country up to 0.59 in the east (Annaba). This is due to the proximity to the Mediterranean and the surrounding relief; whatever the flow direction, there is always formation of depression and thus the presence of cyclogenesis. The increased baroclinic instability in saturated air is closely related to latent heat release and thus to the development of convective phenomena. Moreover, during the rainy season (December-January), northern Algeria is affected by the polar front, especially the east of the country, which is much wetter than west. The map analyzed presents considerable geographic cohesion and identifies the region of the most concentrated daily rainfall and intensity of the most critical and aggressive rains.

By analyzing the CI values in the highlands of the country, it was observed that the CI values ranged from 0.57 to 0.62 throughout the country (average of 0.61 ) except for the Biskra area, in which maximum CI value was reached $(\mathrm{CI}=0.70)$ (Table 3 and Fig. 5). These highlands are generally affected by western disturbances following the orographic forcing that causes thunderstorms with heavy rainfall that sometimes results in floods in some areas. The high Biskra value can be explained by the relief, which means that precipitations occur in the northern slope of the Aurès and are dried in its southern side.

The analysis of the southern region of the country shows that the CI values are higher than 0.62 (0.69 in Tindouf, the westernmost region). This is explained by the lack of rain in that part of the country. The lack of rain in the southern region of the country is due to the infiltration of cold or wet air that ascends from low latitudes. The proximity of the Atlantic Ocean allows the maritime air masses to reach the Tindouf area and, in this way, allows some synoptic perturbations that affect this region. The rainy season in the southern part of the country is insummer. This is due to the warm air that ascends due to the adiabatic expansion in the Hoggar. This is often the reason for the occurrence of heavy rains that cause droughts in a relatively short period of time.

In the coastal areas of the country or central and western regions, rains are more or less regular (Mediterranean perturbations produce high daily concentrations), whereas in the eastern region, daily rains are more regular. In general, daily precipitation is more regular in highlands. Towards the south, rains are aggressive and the total daily precipitation can only be equal to the total yearly.

\subsubsection{Study of correlation between the concentration index and the parameters study}

The values of Pearson's correlation coefficient, Spearman's rho and Kendall's tau- $b$ were calculated for each pair of variables (CI, $P$; CI, CV; CI, $N$ ) (Table 4) and show that the correlation is significant at the respective significance $\alpha=0.01$ and $\alpha=0.05$. Indeed, the correlation between CI and the annual precipitation $(P)$ is significant and negative, and a high value of about -0.43 ( $p<0.01)$ is obtained for the Pearson's correlation coefficient (i.e., the rainfall concentration on a small number of rainy days is apparently greater in areas with low annual means). However, the correlation between $\mathrm{CI}$ and the annual variation coefficient is significant and positive: $0.54(p<0.01)$. This result seems related to the rainfall behavior on an annual scale and on a daily scale, further supporting the hypothesis that a very small number of rainy days can change the yearly rainfall behavior (wet or dry). On the annual number of rainy days and CI, they are negatively related $(-0.53)$ and the correlation is significant at 0.05 .

\subsection{Comparison between the CI results in Algeria and other countries}

The results of the CI values in Algeria and in other countries, such as mainland Spain (Martin-Vide, 2004), Iran (Alijani et al., 2008) and China (Zhang et al., 2009), show that the CI values obtained in all Algerian territory are similar to those found in peninsular Spain and Iran and they are lower than those found in China.

Indeed, the CI of series of precipitation varies between 0.57 and 0.70 for Algeria (an average of 0.63 for the period from 1970 to 2008), between 0.55 and 0.70 for peninsular Spain (an average of 0.61 for the period from 1951 to 1990), between 0.58 and 0.73 for Iran (an average of 0.64 for the period from 1961 to 1990) and between 0.74 and 0.80 for China (for the period from 1960 to 2005). It was observed that the CI values of peninsular Spain and Algeria are similar but do not have the same interpretation. For example, the concentration index value in Biskra $(\mathrm{CI}=0.70)$ is explained by the lack of rainfall in this part of the country $\left(125 \mathrm{~mm} \mathrm{yr}^{-1}\right)$, while $\mathrm{CI}=0.70$ for Valencia (Martin-Vide, 2004) is explained by the relatively large amount of precipitation $\left(472 \mathrm{~mm} \mathrm{yr}^{-1}\right)$. This shows that the CI value is closely linked with the in- 
Table 4. Values of Pearson's correlation coefficient, Spearman's rho and Kendall's tau- $b$ for three pairs of variables: (CI, $P$ ), (CI, CV) and $(\mathrm{CI}, N)$.

\begin{tabular}{lccc}
\hline Type of correlation & $\begin{array}{r}\text { Pearson's } \\
\text { correlation } \\
\text { coefficient }\end{array}$ & $\begin{array}{r}\text { Spearman's } \\
\text { rho }\end{array}$ & $\begin{array}{r}\text { Kendall's } \\
\text { tau- } b\end{array}$ \\
\hline $\begin{array}{l}\text { Between concentration } \\
\text { index and the } \\
\text { annual precipitation }\end{array}$ & -0.43 & -0.50 & -0.32 \\
\hline $\begin{array}{l}\text { Between concentration } \\
\text { index and the } \\
\text { annual variation } \\
\text { coefficient }\end{array}$ & 0.54 & 0.61 & 0.44 \\
\hline $\begin{array}{l}\text { Between concentration } \\
\text { index and the } \\
\text { annual number of rainy } \\
\text { days }\end{array}$ & -0.53 & -0.54 & -0.37 \\
\hline Significance levels & & & \\
\hline Decision of test & \multicolumn{3}{c}{$0.01 ; 0.05$} \\
\hline
\end{tabular}

tensity and not with the amount of rainfall. The CI values in Algeria are less than those calculated by Zhang et al. (2009) in China; this might be due to different climatic systems existing in these two countries. In fact, Algeria is dominated by two types of training climates: Mediterranean and Saharan African. The Saharan climate, a hot tropical desert climate, covers $80 \%$ of the surface of Algeria, which is characterized by large seasonal and daily variations of temperature and very low and irregular rainfall. Annual precipitation lower than $20 \mathrm{~mm} \mathrm{yr}^{-1}$ is recorded in some regions in the extreme southeast (Illizi, Bordj Badji Mokhtar, Adrar). The Pearl River basin in China is characterized by a current climate of temporal and spatial distribution with highly irregular rainfall. In addition, the amount of precipitation in the Pearl River basin is usually the result of precipitation due to storm and convection. This can cause increases in the concentration index values in comparison to those of Algeria.

The main effects of the high daily concentration of precipitation in northern as well southern Algeria produce soil erosion, floods and landslides.

\section{Conclusions}

The daily rainfall concentration in the region of Biskra and in the southwestern part of the country is high, with concentration index values close to 0.70 . This reflects the fact that very few rainy days are bringing a high percentage of annual precipitation.

The occurrence or not of such large quantities every day can change the character (dry or wet) of any month, season or year. This leads to considerable uncertainty in the average rainfall contributions, which in turn leads to environmental and social impacts.

Thus, it was concluded that in Algeria, the essential features of climate in different regions are characterized by narrow climatic zones close to the coast, under the combined influence of the sea. The relief of the soil, the latitude and the diversity of climates in Algeria lead to a very different rainfall distribution.

The CI values obtained at 42 meteorological stations across Algeria range from 0.70 (Biskra) to 0.57 (M'sila). Tracing isohyets are also largely determined by the topography of the surface. Northern, western and central regions are areas where rainfall is regular compared to eastern regions, while the southern region shows the most aggressive rainfall.

\section{The Supplement related to this article is available online at doi:10.5194/nhess-15-617-2015-supplement.}

Acknowledgements. This research was a collaboration between the National Climate Center of Algeria and the Climatology Group (part of project CGL2011-29263-C02-01, 2012-2014) and research group 443 GenCat at the University of Barcelona. The database was provided by the National Meteorological Office of Algeria.

Edited by: P. Nastos

Reviewed by: two anonymous referees

\section{References}

Alijani, B., O’Brien, J., and Yarnal, B.: Spatial analysis of precipitation intensity and concentration in Iran, Theor. Appl. Climatol., 94, 107-124, 2008.

Benhamrouche, A. and Martin-Vide, J.: Distribución Espacial de la Concentración Diaria de la Precipitación en la Provincia de Alicante, Inves Geogr., 56. 113-129, 2011.

Benhamrouche, A. and Martin-Vide, J.: Avances metodológicos en el análisis de la concentración diaria de la precipitación en la España peninsular, Anal. de Geogr. 32, 11-27, 2012.

Cortesi, N., González-Hidalgo, J. C., Brunetti, M., and MartinVide, J.: Daily precipitation concentration across Europe 1971-2010, Nat. Hazards Earth Syst. Sci., 12, 2799-2810, doi:10.5194/nhess-12-2799-2012, 2012.

Coscarelli, R. and Caloiero, T.: Analysis of daily and monthly rainfall concentration in Southern Italy (Calabria region), J. Hydrol., 416-417, 145-156, 2012.

De Luis, M., Conzalez-Hidalgo, J. C., and Sánchez, J. R.: Análisis de la distribución espacial de la concentración diaria de precipitaciones en el territorio de la comunidad valenciana, Cuad. de Geogr., 59, 47-62, 1996.

De Luis, M., Conzalez-Hidalgo, J. C., Raventós, J., and Sánchez, J. R.: Distribución espacial de la concentración y agresividad de la lluvia en el territorio de la Comunidad Valenciana, Cuat. Geomor., 11, 33-44, 1997. 
Jolliffe, I. T. and Hope, P. B.: Representation of daily rainfall distributions using normalized rainfall curves, Int. J. Climatol., 16. 1157-1163, 1996.

Martin-Vide, J.: Geographical factors in the pluviometry of Mediterranean Spain: drought and torrential rainfall. In U.S.Spain Workshop on Natural Hazards, Iowa. Inst. Hydra Res., The University of Iowa, 9-25, 1994.

Martin-Vide, J.: Spatial distribution of a daily precipitation concentration index in Peninsular Spain, Int. J. Climatol., 24, 959-971, 2004.
Olascoaga, M. J.: Some aspects of Argentine rainfall, Tellus B, 2, 312-318, 1950.

Riehl, H.: Some aspects of Hawaiian rainfall, BAMS, 30, 76-187, 1949.

Sánchez-Lorenzo, A. and Martin-Vide, J.: Distribución espacial de la concentración pluviométrica diaria en la Península Ibérica. Proceedings $5^{a}$ Asamblea Hispano Portuguesa de Geodesia y Geofísica, sesión Climatología y Cambio Climático, 2006.

Zhang, Q., Xu, C. Y., Gemmer, M., Chen, Y. Q., and Liu, C. L.: Changing properties of precipitation concentration in the Pearl River basin, China, Stoch. Env. Res. Risk A., 23, 377-385, 2009. 